\title{
PELAKSANAAN EVALUASI FORMATIF MATA PELAJARAN EKONOMI PADA KELAS XI DI MADRASAH ALIYAH AL-BADAR KASONGAN
}

\author{
SUPARDI \\ Dosen Fakultas Keguruan dan IImu Pendidikan Universitas Muhammadiyah Palangkaraya
}

\begin{abstract}
Difficulties experienced by teachers in the implementation of formative evaluation occurs due to several related factors, among others: the mastery of concepts and attitudes of the teachers about the evaluation function, evaluation of management, school management, as well as the limited means of support facilities in supporting the implementation of a good evaluation. So, the focus of this research is on how the implementation of Formative Evaluation of Economic Subjects in the class XI of Aliyah Al-Badar Kasongan academic year 2013-2014. This study aims to determine the Formative Evaluation of the Implementation of Economic Subjects in class XI in Aliyah Al-Badar Lessons Kasongan academic years 2013-2014. In this study used a qualitative approach. The subjects of the study consisted of a Principal, Teachers and Learners. To get the data the researchers used several methods, namely: Interview, observation, and documentation. Analysis was performed with data reduction, data display, draw conclusions and verification of data.

Results of the study 1) Planning is the preparation done by teachers in economics before carrying out formative evaluation, namely to create a syllabus and lesson plans, so that the implementation of formative evaluation can be run properly. 2) Implementation of formative evaluation of economic subjects held in Aliyah Al - Badar is in conformity with the relevant teacher planning, even in learning system that is taught to students of economic subjects has been going well despite the shortcomings, especially infrastructure and facilities such as libraries, laboratories and textbooks are very minimal. 3) Follow up of the results of the formative evaluation, after carrying out formative evaluation of the test results will be notified to the learning outcomes of students who either can continue to the next lesson, but for the students who have not reached the learning outcomes KKM will be held remedial for improvement results. 4) Constraints in the learning process faced by teachers is mastery of the material, therefore the teachers of economics should be ready in the mastery of the material that will be presented to the learner. 5) Efforts are made by teachers of economics in the implementation of formative evaluation done with good planning, knowledge and skills are adequate and careful preparation, so that the test can measure compiled formative high and low ability of the learners.
\end{abstract}

Key words: evaluation, formative

\begin{abstract}
ABSTRAK
Kesulitan yang dialami guru dalam pelaksanaan evaluasi formatif terjadi karena beberapa faktor yang terkait, antara lain: penguasaan konsep dan sikap guru tentang fungsi evaluasi, pengelolaan evaluasi, manajemen sekolah, serta masih terbatasnya sarana pendukung dalam menunjang proses pelaksanaan kegiatan evaluasi yang baik. Sehingga fokus penelitian pada bagaimana Pelaksanaan Evaluasi Formatif Mata Pelajaran Ekonomi pada kelas XI di Aliyah Al-Badar Kasongan tahun pelajaran 2013-2014?. Penelitian ini bertujuan untuk mengetahui Pelaksanaan Evaluasi Formatif Mata Pelajaran Ekonomi pada kelas XI di Aliyah Al-Badar Kasongan tahun Pelajaran 2013-2014. Dalam penelitian ini menggunakan pendekatan kualitatif. Subyek penelitian terdiri dari Kepala Sekolah, Guru dan Peserta didik. Untuk mendapatkan data peneliti menggunakan beberapa metode, yaitu: Interview atau Wawancara, Observasi, dan Dokumentasi. Analisis dilakukan dengan reduksi data, display data, mengambil kesimpulan dan verifikasi data. Hasil penelitian 1). Perencanaan merupakan persiapan yang dilakukan oleh guru bidang studi ekonomi sebelum melaksanakan evaluasi formatif, yaitu menyusun silabus dan RPP, sehingga pelaksanaan evaluasi formatif dapat berjalan dengan baik. 2). Pelaksanaan evaluasi formatif mata pelajaran ekonomi yang dilaksanakan di Aliyah Al-Badar sudah sesuai dengan perencanaan guru yang bersangkutan, bahkan sistem pembelajaran yang diajarkan kepada peserta didik mata pelajaran ekonomi sudah berjalan
\end{abstract}


dengan baik walaupun terdapat kekurangan-kekurangan terutama sarana dan prasarana seperti perpustakaan, laboraturium dan buku paket yang sangat minim. 3). Tindaklanjut hasil evaluasi formatif, setelah melaksanakan evaluasi formatif hasil tes tersebut akan diberitahukan kepada peserta didik yang hasil belajarnya baik dapat meneruskan ke pelajaran selanjutnya, tetapi bagi peserta didik yang hasil belajarnya belum mencapai KKM akan diadakan remedial untuk perbaikan hasilnya. 4). Kendala dalam proses pembelajaran yang dihadapi oleh guru adalah penguasaan materi, karena itu guru bidang studi ekonomi harus siap dalam penguasaan materi yang akan disampaikan kepada peserta didik. 5). Upaya yang dilakukan guru bidang studi ekonomi dalam pelaksanaan evaluasi formatif melakukan perencanaan dengan baik, pengetahuan dan keterampilan yang memadai serta persiapan yang cermat, agar tes formatif yang disusun dapat mengukur tinggi rendahnya kemampuan peserta didik

Kata kunci : evaluasi, formatif

\section{PENDAHULUAN}

\section{Latar Belakang}

Pendidikan pada dasarnya merupakan suatu proses mengubah tingkah laku dalam usaha untuk membantu, mendorong dan mengarahkan manusia agar berkembang secara maksimal dalam mencapai tujuan pendidikan. Tugas pendidikan nasional sebagaimana yang tercantum pada Pasal 1 Ayat (1) Undang-undang Republik Indonesia No 20 Tahun 2003 tentang Sistem Pendidikan Nasional yang menyatakan bahwa:

Pendidikan adalah usaha sadar dan terencana untuk mewujudkan suasana belajar dalam proses pembelajaran agar peserta didik secara aktif mengembangkan potensi dirinya untuk memiliki kekuatan spiritual keagamaan, pengendalian diri, kepribadian, kecerdasan, akhlak mulia, serta keterampilan, yang diperlukan dirinya, masyarakat bangsa dan Negara.

$$
\text { Fungsi dan tujuan pendidikan }
$$

berdasarkan Pasal 3 Ayat 2 Undang-undang Republik Indonesia No 20 Tahun 2003 tentang Sistem Pendidikan Nasional yang menyatakan:

Pendidikan nasional berfungsi mengembangkan kemampuan untuk membentuk watak serta peradaban bangsa yang bermartabat dalam rangka mencerdaskan kehidupan bangsa, bertujuan untuk berkembangnya potensi peserta didik agar menjadi manusia yang beriman, bertaqwa Kepada Tuhan Yang Maha Esa, berakhlak mulia, sehat, berilmu cakap, kreatif, mandiri, dan menjadi negara yang demokrasi serta tanggung jawab.

Sedangkan menurut Lukmanul Hakim (2008: 66) yang mengutip dari Hilda Taba mengemukakan bahwa secara garis besar pandangan tentang fungsi pendidikan terutama pendidikan formal di sekolah dapat dikelompokkan kedalam tiga macam yaitu:

1. Pendidikan berfungsi memelihara dan menyampaikan warisan kebudayaan kepada generasi muda.

2. Pendidikan berfungsi mengubah dan memperbaiki kebudayaan.

3. Pendidikan berfungsi mengembangkan kemampuan, kecakapan, dan pribadi setiap individu.

Berdasarkan kutipan tersebut jelas bahwa titik sentral segala aktivitas pendidikan yakni bertujuan untuk meningkatkan kualitas sumber daya manusia, menciptakan generasi bangsa yang terampil, maju, cerdas, tangguh, beretos kerja, profesional, mandiri, serta bertaqwa Kepada Tuhan Yang Maha Esa dalam kondisi sehat jasmani dan rohani. Untuk mewujudkan itu diperlukan upaya meningkatkan keberhasilan pembelajaran yang dimulai dari pendidikan yang profesional, komponen sistem pembelajaran yang baik serta menyediakan sarana menyangkut upaya meningkatkan mutu pendidikan. 
Setiap usaha atau kegiatan instruksional sebaiknya diikuti dengan tindak lanjut, yaitu kegiatan evaluasi. Evaluasi ini seyogyanya dilakukan karena merupakan salah satu komponen utama yang perlu ada pada setiap sistem instruksional. Dengan demikian tanpa evaluasi suatu sistem instruksional masih dapat dikatakan belum lengkap. Dalam bidang pendidikan, kegiatan evaluasi merupakan kegiatan utama yang tidak dapat ditinggalkan. Begitu juga proses evaluasi pada kegiatan belajar mengajar hampir terjadi setiap saat, tetapi formalitasnya berbeda-beda. Evaluasi berhubungan erat dengan tujuan instruksional, analisis kebutuhan dan proses belajar mengajar. Dalam proses belajar mengajar perencanaan pembelajaran menjadi salah satu alat penting bagi guru. Guru yang baik akan selalu membuat perencanaan untuk kegiatan pembelajaran, maka tidak ada alasan di kelas tanpa perencanaan pembelajaran.

Perencanaan evaluasi formatif yang disiapkan oleh guru mata pelajaran ekonomi kelas XI Aliyah Al-Badar Kasongan merupakan sesuatu yang diidealisasikan atau dicita-citakan. Apa yang tertuang dalam perencanaan pembelajaran evaluasi formatif yang disiapkan guru mata pelajaran ekonomi Aliyah Al-Badar Kasongan semuanya merupakan keinginan-keinginan yang hendak dicapai dalam tujuan pembelajaran. Setiap keinginan ada kalanya dapat tercapai dan adakalanya tidak dapat tercapai. Sedangkan keberhasilan merupakan suatu upaya yang ditentukan oleh berbagai faktor. Faktor yang paling mendasar adalah kemampuan seseorang guru melakukan upaya dalam mewujudkan apa yang dinginkan. Perencanaan evaluasi formatif yang dibuat merupakan antisipasi dan perkiraan tentang apa yang akan dilakukan dalam pembelajaran, sehingga tercipta suatu situasi yang memungkinkan terjadinya proses belajar yang dapat mengantar peserta didik mencapai tujuan yang diharapkan. Untuk mencapai tujuan yang diharapkan perlu adanya kegiatan pelaksanaan evaluasi formatif.

Kegiatan pelaksanaan evaluasi formatif di sekolah dilaksanakan secara periodik selama proses pembelajaran berlangsung yang dilakukan dalam bentuk pemberian tugas, ulangan harian, dan ulangan tengah semester. Kegiatan pelaksanaan evaluasi formatif yang dilakukan guru mata pelajaran ekonomi Aliyah Al-Badar Kasongan merupakan aktualisasi dari unsur-unsur yang terdapat dalam perencanaan, pengelolaan, analisis soal, pemanfaatan tes dan tindak lanjut hasilnya. Hasil pelaksanaan kegiatan evaluasi formatif yang baik akan dapat bermanfaat sebagai umpan balik bagi guru mata pelajaran ekonomi. Pemanfaatan evaluasi formatif dimaksudkan sebagai kegiatan-kegiatan yang dilakukan guru mata pelajaran ekonomi dalam memanfaatkan hasil evaluasi tersebut sesuai dengan fungsinya, yaitu untuk meningkatkan motivasi belajar peserta didik, sebagai acuan pola mengajar guru mata pelajaran ekonomi dan memperbaiki pola belajar peserta didik. Berdasarkan hasil observasi pada Aliyah Al-Badar Kasongan bahwa, pelaksanaan evaluasi formatif mata pelajaran ekonomi pada kelas XI sudah berjalan dengan baik. Walaupun terdapat kekurangan-kekurangan sarana dan prasarana terutama pada buku paket yang sangat minim untuk menunjang proses pembelajaran. 
Agar pelaksanaan evaluasi formatif dapat mencapai tujuan dan fungsinya dengan baik, maka diperlukan beberapa langkah yang dapat dijadikan pegangan dalam melaksanakannya, yaitu: merumuskan atau mempertegas tujuantujuan pengajaran, agar dapat memberikan arah terhadap penyusunan alat penilaian yang akan digunakan, menyusun alat-alat penilaian, baik berupa tes maupun non tes yang cocok digunakan dalam menilai jenis tingkah laku yang tergambar dalam tujuan pengajaran, menggunakan hasil-hasil penilaian sesuai dengan tujuan penelitian, yaitu untuk mendeskripsikan kemampuan peserta didik, perbaikan pengajaran, dan laporan pertanggungjawaban, merumuskan tujuan instruksional/ kompetensi dasar secara operasional agar dapat diukur dengan alat penilaian yang digunakan, membuat kisi-kisi alat penilaian agar dapat diketahui abilitas yang diukur serta proporsinya, menyusun butir-butir tes yang telah dibuat berdasarkan aturan yang baku, membuat dan menentukan kunci jawaban soal (Sudjana, 2004: 10). Pelaksanaan kegiatan evaluasi formatif dengan mengacu pada langkahlangkah tersebut diharapkan dapat mencapai tujuan evaluasi dengan baik, yaitu menghasilkan evaluasi yang akurat. Berdasarkan informasi yang diperoleh dari hasil evaluasi formatif, guru mata pelajaran ekonomi dapat menetapkan metode, teknik, dan strategi mengajar yang lebih tepat dalam menyusun kegiatan-kegiatan tindak lanjut berupa program remedial maupun pengayaan pelajaran sebelum materi berikutnya diajarkan.

Evaluasi formatif dalam kegiatan pembelajaran merupakan salah satu sub sistem yang sangat penting karena diperlukan untuk memperbaiki proses dan hasilnya. Hasil evaluasi formatif bagi guru mata pelajaran ekonomi untuk mengetahui perkembangan ketuntasan belajar peserta didik secara klasikal yang dapat dimanfaatkan untuk memprediksi keberhasilan dalam evaluasi yang lebih luas, seperti: sumatif. Guru yang baik adalah guru yang selalu membangun motivasi, minat, kegairahan, dan ketekunan yang tinggi dalam belajar agar dapat mencapai hasil belajar yang optimal. Uzer Usman (2005: 30) menyatakan bahwa:

Kegiatan evaluasi formatif yang dikelola dengan baik dapat dimanfaatkan oleh guru untuk meningkatkan motivasi belajar kepada peserta didik, karena pada umumnya peserta didik selalu belajar lebih giat apabila mengetahui akan diadakan ujian dengan harapan dapat memperoleh prestasi yang tinggi dalam hasil ujian tersebut.

Namun dalam kenyataan, peluang ini tidak dimanfaatkan oleh semua guru secara optimal. Kesulitan ini terjadi karena beberapa faktor yang terkait, antara lain seperti: penguasaan konsep dan sikap guru tentang fungsi evaluasi, pengelolaan evaluasi, manajemen sekolah, serta masih terbatasnya sarana pendukung dalam menunjang proses pelaksanaan kegiatan evaluasi yang baik.

Perencanaan diperlukan suatu pengetahuan, kemampuan dan keterampilan yang memadai. Tes yang dibuat tanpa perencanaan yang matang dan dapat dipertanggungjawabkan akan menjadi sia-sia bahkan tidak mungkin menghasilkan informasi yang akurat dan dapat menggagu proses pencapaian tujuan belajar. Pelaksanaan aktualisasi dari unsur-unsur yang terdapat dalam perencanaan, pengelolaan analisis soal, pemanfaatan tes, dan tindaklanjut hasilnya. Hasil kegiatan pelaksanaan kegiatan 
evaluasi yang baik akan dapat bermanfaat sebagai umpan balik bagi guru, pemanfaatan evaluasi tersebut sebagai kegiatan-kegiatan yang dilakukan guru dalam memanfaatan hasil evaluasi tersebut sesuai dengan fungsinya, yaitu: untuk meningkatkan motivasi belajar peserta didik, sebagai acuan pola mengajar guru, dan perbaikan pola belajar peserta didik. Tindaklanjut evaluasi formatif, setelah peserta didik melaksanakan tes formatif yang diberikan oleh guru yang bersangkutan, hasil evaluasi tersebut akan diberitahukan kepada peserta didik yang bersangkutan agar mereka dapat mengetahui keberhasilan dan kegagalan dalam proses pembelajaran. Evaluasi formatif yang demikian benar-benar berfungsi sebagai umpan balik, suapaya mereka mengetahui dimana letak kelemahanya dalam proses pembelajaran pada masing-masing peseta didik.

Berdasarkan uraian di atas, peneliti ingin mengetahui bagaimana pelaksanaan evaluasi formatif mata pelajaran ekonomi pada kelas $\mathrm{XI}$ di Aliyah Al-Badar Kasongan mulai dari perencanaan, pelaksanaan, dan tindak lanjut dari hasil evaluasi formatif. Oleh karena itu, peneliti tertarik untuk melakukan penelitian "Pelaksanaan Evaluasi Formatif Mata Pelajaran Ekonomi Pada Kelas XI di Aliyah Al-Badar Kasongan Tahun Pelajaran 2013-2014".

\section{Fokus Penelitian}

Berdasarkan masalah yang telah diuraikan sebelumnya, maka dapat dirumuskan fokus penelitian pada bagaimana Pelaksanaan Evaluasi Formatif Mata Pelajaran Ekonomi pada kelas XI di Aliyah Al-Badar Kasongan tahun pelajaran 20132014 ?

\section{Tujuan Penelitian}

Tujuan penelitian ini adalah untuk mengetahui Pelaksanaan Evaluasi Formatif Mata Pelajaran Ekonomi pada kelas XI di Aliyah Al-Badar Kasongan tahun Pelajaran 2013-2014.

\section{Manfaat Penelitian}

Ada beberapa manfaat yang diharapkan, yaitu: 1).Secara teoretis bagi pengembangan keilmuan, memberikan sumbangan informasi tentang evaluasi formatif mata pelajaran ekonomi. 2). Secara Praktis bermanfaat bagi Kepala sekolah dapat memberikan masukan kepada para guru bahwa pelaksanaan keberhasilan evaluasi formatif merupakan proses pembelajaran yang bertujuan untuk memonitor kemajuan belajar peserta didik dan bagi guru sebagai acuan dalam memperbaiki kinerja.

\section{Pendekatan dan Jenis Penelitian}

Dalam penelitian ini menggunakan pendekatan kualitatif. Artinya data-data yang dikumpulkan bukan berupa angka-angka, melainkan kategorisasi. Data tersebut berasal dari naskah wawancara, catatan lapangan, dokumen pribadi, catatan memo, dan dokumen resmi lainnya. Sehingga yang menjadi tujuan adalah ingin menggambarkan realita empirik di balik fenomena secara mendalam, rinci dan tuntas. Oleh karena itu penggunaan pendekatan kualitatif dalam penelitian ini adalah dengan mencocokan antara realita empirik dengan teori yang berlaku dengan menggunakan metode deskriptif.

Pertimbangan peneliti menggunakan penelitian kualitatif ini sebagaimana yang diungkapkan oleh Lexy Moleong, (2010: 10) yaitu: 1). Menyesuaikan metode kualitatif lebih mudah apabila berhadapan dengan kenyataan ganda/jamak. 2). Metode ini secara tidak 
langsung menggambarkan hakikat hubungan antara peneliti dan responden.

\section{Subjek dan Data Penelitian}

Subjek yang diteliti dalam penelitian kualitatif memiliki kedudukan yang sama dengan peneliti. Hal ini sebagaimana dikemukakan oleh Nasution dalam Hasan, (2012: 38) menyatakan bahwa:

Subjek yang diteliti dipandang memiliki kedudukan yang sama dengan peneliti, jadi tidak sebagai objek atau yang lebih rendah kedudukannya, akan tetapi sebagai manusia setaraf. Peneliti tidak menganggap dirinya lebih tinggi atau lebih tahu. la datang untuk belajar, untuk menambah pengetahuan dan pemahamannya.

Berdasarkan pernyataan di atas, peneliti menyatakan bahwa objek yang diteliti dalam penelitian ini sekaligus bertindak sebagai subjek penelitian. Oleh karena itu, dalam penelitian ini Aliyah Al-Badar Kasongan merupakan objek penelitian, sedangkan berdasarkan data dan informasi yang diperlukan dalam penelitian ini serta rumusan masalah yang telah ditetapkan.

Adapun sasaran penelitian yaitu:

1. Kepala sekolah sebagai orang yang pertama yang mengetahui tentang pelaksanaan evaluasi formatif pelajaran ekonomi.

2. Guru yang bertindak sebagai pelaksanaan evaluasi formatif pelajaran ekonomi.

3. Peserta didik yang bertindak sebagai pengguna evaluasi formatif pelajaran ekonomi.

\section{Kehadiran Peneliti}

Dalam penelitian ini, peneliti sebagai pengumpul data dan sebagai instrumen aktif dalam upaya mengumpulkan data-data di lapangan. Sedangkan instrumen pengumpulan data yang lain berbagai bentuk alat-alat bantu yang berupa dokumen-dokumen lainnya yang digunakan untuk menunjang keabsahan hasil peneliti, namun berfungsi sebagai instrumen pendukung. Oleh karena itu, kehadiran peneliti secara langsung di lapangan sebagai tolok ukur keberhasilan untuk memahami kasus yang diteliti, sehingga keterlibatan peneliti secara langsung dan aktif dengan informan dan sumber data lainnya disini mutlak dipergunakan.

\section{Prosedur Pengumpulan Data}

Untuk mendapatkan data yang relevan sesuai dengan apa yang diharapkan, maka peneliti akan menggunakan beberapa metode, yaitu: Interview atau Wawancara, Observasi, dan Dokumentasi.

\section{Analisis Data}

Proses pelaksanaan analisis data dalam penelitian ini dilakukan sejak awal pengumpulan data dan dikerjakan secara intensif setelah meninggalkan lapangan. Analisis data dilakukan secepatnya oleh peneliti agar data yang didapat tidak baku atau kadaluarsa.

1. Reduksi Data

Merupakan kegiatan penelitian dalam melakukan pencatatan dan menelaah berbagai data dan informasi yang telah peneliti dapatkan. Setelah dikaji langkah berikutnya adalah membuat rangkuman untuk setiap kontak atau pertemuan dengan responden. Dalam merangkum dan biasanya ada satu unsur yang tidak dapat dipisahkan dengan kegiatan tersebut yang disebut dengan abstraksi, yaitu membuat ringkasan yang inti, proses dan persyaratan yang berasal dari responden tetap dijaga. Dari rangkuman yang dibuat ini kemudian peneliti melakukan reduksi data yang kegiatannya mencakup unsur-unsur spesifik. Kegiatan lain 
yang masih dalam reduksi data yaitu memfokuskan, menyederhanakan dan mentransfer dari data kasar ke catatan lapangan. Peneliti seharusnya sering memeriksa dengan cermat hasil catatan yang diperoleh dari setiap terjadi kontak antara peneliti dengan responden.

2. Display Data

Proses display data peneliti menyusun data yang relevan, sehingga menjadi informasi yang dapat disimpulkan memiliki makna tertentu dengan cara menampilkan dan membuat hubungan antara variabel agar peneliti lain atau pembaca laporan penelitian mengerti apa yang telah terjadi dan apa yang perlu ditindak lanjut untuk mencapai tujuan peneliti.

3. Menampilkan Kesimpulan dan Verifikasi

Dari awal pencarian data sampai pada tahap analisis, tujuan yang diinginkan oleh peneliti berusaha untuk mencari makna data yang dikumpulkannya. Sehingga kesimpulan dapat diperoleh dari satu kegiatan yang berkesinambungan dari awal hingga akhir penelitian. Untuk itu peneliti mencari pola, tema, hubungan persamaan, hal-hal yang sering timbul, dan lain sebagainya. Kesimpulan senantiasa harus diverifikasi selama penelitian berlangsung.

\section{Pengecekan Keabsahan Data}

Dalam pengumpulan data dan informasi dari beberapa cara yang telah diuraikan, peneliti perlu melakukan pengecekan terhadap keabsahan data dilakukan dengan prosedur triangulasi, menggunakan bahan referensi dan member check.
1. Triangulasi

Triangulasi merupakan teknik pemeriksaan keabsahan data yang memanfaatkan sesuatu yang lain di luar data itu untuk keperluan pengecekan atau pembanding terhadap data itu. Dalam pelaksanaannya dengan membandingkan data atau informasi tentang pelaksanaan evaluasi formatif pada kelas XI di Aliyah AlBadar Kasongan dari berbagai sumber yang mengetahui permasalahan secara mendalam.

2. Bahan Referensi

Penggunaan bahan referensi digunakan untuk meningkatkan kepercayaan atau kebenaran data, peneliti dapat menggunakan hasil wawancara dalam bentuk rekaman tape atau video tape atau bahan dokumentasi tentang evaluasi formatif.

3. Member check

Pada akhir wawancara kita ulangi dalam garis besarnya berdasarkan catatan kita, apa yang telah dikatakan responden dengan maksud agar dapat memperbaiki atau menambahkan apa yang masih belum lengkap. Jadi tujuan member check adalah agar informasi yang diperoleh dan digunakan dalam penulisan laporan sesuai dengan apa yang dimaksud oleh informasi.

\section{Temuan Penelitian}

Temuan data-data selama penelitian pelaksanaan evaluasi formatif mata pelajaran ekonomi yang dilaksanakan oleh guru ekonomi di Aliyah Al-Badar Kasongan dapat dideskripsikan tentang upaya yang dilakukan dan bagaimana pelaksanaannya. 
Beberapa hal tentang pelaksanaan evaluasi formatif mata pelajaran ekonomi, masih ada kendala dalam pelaksanaanya tetapi tidak menjadi hambatan yang berarti bagi sekolah ini karena sudah ada upaya untuk mengatasinya.
Hasil wawancara dengan responden tentang pelaksanaan evaluasi formatif mata pelajaran ekonomi pada Aliyah Al-Badar Kasongan disajikan pada Tabel 1.

Tabel 1. Hasil temuan penelitian pelaksanaan evaluasi fomatif mata pelajaran ekonomi pada kelas XI di Madrasah Aliyah AI-Badar Kasongan

\begin{tabular}{|c|c|c|}
\hline No & Komponen & Keadaan \\
\hline 1. & $\begin{array}{l}\text { Perencanaan } \\
\text { evaluasi formatif }\end{array}$ & $\begin{array}{l}\text {....sebelum melaksanakan evaluasi formatif saya harus menyusun } \\
\text { silabus dan RPP, sebagai pegangan guru dalam aktivitas } \\
\text { pembelajaran. Jadi materi yang diajarkan sudah direncanakan } \\
\text { sebelum dilaksanakannya proses pembelajaran.....(Wawncara: } \\
\text { IF/29/11/2013) }\end{array}$ \\
\hline 2. & $\begin{array}{l}\text { Upaya yang dilakukan } \\
\text { guru bidang studi } \\
\text { dalam pelaksanaan } \\
\text { evaluasi formatif }\end{array}$ & $\begin{array}{l}\text {... melakukan perencanaan evaluasi dengan baik. Dalam membuat } \\
\text { perencanaan tes formatif diperlukan pengetahuan dan keterampilan } \\
\text { yang memadai serta persiapan yang cermat agar tes yang dususun } \\
\text { mampu mengukur kemampuan peserta didik.... (Wawancara: } \\
\text { IF/29/11/2013) }\end{array}$ \\
\hline 3. & $\begin{array}{l}\text { Pelaksanaan evaluasi } \\
\text { formatif dan } \\
\text { tindaklanjut hasilnya }\end{array}$ & $\begin{array}{l}\text {.... perencanaan, pelaksanaan maupun hasil evaluasi formatif saya } \\
\text { kira titik akhirnya adalah menginginkan daripada kegiatan belajar } \\
\text { mengajar pelajaran pelajaran ekonomi yang diajarkan di kelas itu bisa } \\
\text { diserap secara totalitas oleh peserta didik, sehingga apa yang } \\
\text { dilakukan oleh guru yang bersangkutan dijadikan bahan pelajaran } \\
\text { untuk mengikuti ujian sekolah....(Wawancara: AL/2/12/2013) }\end{array}$ \\
\hline 4. & $\begin{array}{l}\text { Pelaksanaan evaluasi } \\
\text { formatif sebelum } \\
\text { diadakannya ulangan } \\
\text { semester ganjil }\end{array}$ & $\begin{array}{l}\text {... evaluasi formatif ada yang diberitahukan terlebih dahulu sebelum } \\
\text { dilaksanakan agar peserta didik mengingat dan menjawab pertanyaan- } \\
\text { pertanyaan yang diberikan dengan tepat. Kemudian ada ulangan yang } \\
\text { tidak diberitahukan lebih dahulu untuk menguji ketanggapan..... } \\
\text { (Wawancara: } Z N / 30 / 11 / 2013 \text { ) }\end{array}$ \\
\hline 5. & $\begin{array}{l}\text { Upaya guru bidang } \\
\text { studi ekonomi } \\
\text { memotivasi peserta } \\
\text { didik }\end{array}$ & $\begin{array}{l}\text {... melakukan tindaklanjut dari hasil belajar peserta didik, bagi peserta } \\
\text { didik yang tunta hasil belajarnya maka saya akan memberikan } \\
\text { motivasi, arahan dan bimbingan agar tetap aktif dalam pembelajaran } \\
\text { dengan tujuan meningkatkan kemampuan agar menjadi lebih baik lagi. } \\
\text { Begitu juga dengan halnya peserta didik yang belum tuntas hasil } \\
\text { belajarnya maka saya akan melakukan tindakan pengayaan.... } \\
\text { (Wawancara: IF/29/11/013) }\end{array}$ \\
\hline 6. & $\begin{array}{l}\text { Kendala dalam } \\
\text { pelaksanaan evaluasi } \\
\text { formatif }\end{array}$ & $\begin{array}{l}\text {... kendala yang dihadapi oleh guru bidang studi ekonomi harus siap } \\
\text { untuk menghadapi berbagai permasalahan dalam mata pelajaran itu. } \\
\text { Setip guru ekonomi dalam hal ini berkewajiban untuk mengusai materi } \\
\text { yang terdapat dalam pelajaran ekonomi. Ilmu ekonomi bukan hanya } \\
\text { tata niaga saja, tapi dia mengatur bagaimana tata niaga dalam } \\
\text { atminitrasi. Oleh karena itu guru ekonomi harus siap dalam } \\
\text { penguasaan materi sebab dalam hitung menghitung memerlukan } \\
\text { pemahaman..... (Wawancara: } \mathrm{AL} / 2 / 12 / 2013 \text { ) }\end{array}$ \\
\hline
\end{tabular}


Tabel 1. (lanjutan)

\begin{tabular}{|c|c|c|}
\hline No & Komponen & Keadaan \\
\hline 7. & $\begin{array}{l}\text { Manfaat evaluasi } \\
\text { formatif bagi guru, } \\
\text { mata pelajaran dan } \\
\text { peserta didik }\end{array}$ & $\begin{array}{l}\text {.... evaluasi formatif bermanfaat bagi guru sebagai alat penilaian } \\
\text { pencapaian tujuan program pembelajaran, guru dapat mengetahui } \\
\text { sejauh mana proses pembelajaran. sedangkan manfaat evaluai bagi } \\
\text { peserta didik yaitu dapat digunakan untuk mengetahui kemampuan } \\
\text { pengusaan materinya dan memotivasi peserta didik agar lebih giat lagi } \\
\text { belajar..... (Wawancara: IF/29/11/2013) }\end{array}$ \\
\hline 8. & $\begin{array}{l}\text { Upaya yang dilakukan } \\
\text { kepala sekolah } \\
\text { Aliyah } \\
\text { Al-Badar } \\
\text { membantu untuk } \\
\text { ekonomi bila guru } \\
\text { masalah ada } \\
\text { pelaksanaan evaluasi } \\
\text { formatif }\end{array}$ & $\begin{array}{l}\text {.... memberikan wewenang sepenuhnya kapada guru-guru yang } \\
\text { khususnya rumpun IPS, bagaimana tata kelola mengajar ekonomi atau } \\
\text { rumpun IPS berjalan dengan baik. Ada beberapa guru ekonomi } \\
\text { meminta diadakan leb sore atau pengayaan materi dalam setiap kali } \\
\text { pertemuan. Evaluasi formatif untuk mengetahui sejauh mana } \\
\text { kemampuan peserta didik dalam mata peserta didik terhadap mata } \\
\text { pelajaran tersebut. Jadi hal-hal yang demikian terbatasnya sarana } \\
\text { pendukung dalam proses pembelajaran......(Wawancara: } \\
\text { AL/2/12/2013) }\end{array}$ \\
\hline 9. & $\begin{array}{l}\text { Hubungan kepala } \\
\text { sekolah Aliyah Al- } \\
\text { Badar, guru dan } \\
\text { peserta didik dalam } \\
\text { pelaksanaan evaluasi } \\
\text { formatif serta } \\
\text { hubungan sosial }\end{array}$ & $\begin{array}{l}\text {... sangat harmonis karena kita dalam memberikan waktu mata } \\
\text { pelajaran dari am } 06.30-13 \text {. } 00 \text { WIB itu sudah kita bentuk jadwal } \\
\text { pembelajaran dalam setiap kelas. Artinya apa, ada pertemuan peserta } \\
\text { didik dengan guru dalam setip jam dengan berbagai pariasi mata } \\
\text { pelajaran, dan ini suatu hubungan yang sangat harmonis bisa } \\
\text { dikatakan dengan aturan disiplin kerja. Sedangkan hubungan sosial } \\
\text { dengan mayarakat sangat besar pengaruhnya karena mereka } \\
\text { berinteraksi di tengah tengah masyarakat, karena pada intinya } \\
\text { mempelajari ilmu ekonomi dalam hubungan sosial, bagaimana tata } \\
\text { cara, tata niaga perekonomian dalam lingkungan masyarakat ..... } \\
\text { (Wawancara: AL/2/12/2013) }\end{array}$ \\
\hline
\end{tabular}

\section{PEMBAHASAN}

Pembahasan hasil penelitian, diarahkan pada pengkajian kesimpulan atau permasalahannya suatu temuan mengenai pelaksanaan evaluasi formatif mata pelajaran ekonomi, agar pelaksanaan evaluasi formatif dapat berjalan dengan baik seperti yang kita harapkan.

Tujuan evaluasi formatif adalah untuk mengetahui sejauh mana pencapaian hasil belajar peserta didik setelah mengikuti program pembelajaran tertentu, dalam pelaksanaannya dapat dilakukan ketika program sedang berlangsung yang bertujuan untuk memberikan imformasi umpan balik kepada peserta didik tentang pencapaian atau hasil belajarnya.

\section{Perencanaan evaluasi formatif}

Merupakan persiapan yang dilakukan oleh guru bidang studi ekonomi sebelum melaksanakan evaluasi formatif, yaitu menyusun silabus dan RPP, sehingga pelaksanaan evaluasi formatif dapat berjalan dengan baik.

\section{Pelaksanaan evaluasi formatif}

Kegiatan pelaksanaan evaluasi formatif di sekolah dilakukan secara periodik selama proses pembelajaran berlangsung yang dilakukan dalam bentuk pemberian tugas, ulangan harian, dan ulangan tengah semester. Kegiatan pelaksanaan evaluasi formatif yang dilakukan guru mata pelajaran ekonomi di Aliyah Al-Badar Kasongan merupakan aktualisasi dari unsur-unsur yang 
terdapat dalam perencanaan, pengelolaan, analisis soal, pemanfaatan tes dan tindaklanjut hasilnya. Agar pelaksanaan evaluasi formatif dapat mencapai tujuan dan fungsinya dengan baik, di dalam membuat perencanaan tes memerlukan pengetahuan dan keterampilan yang memadai serta persiapan yang cermat agar tes yang disusun akan mampu mengukur kemampuan peserta didik.

Evaluasi formatif dilaksanakan dua kali setiap satu bab, guru bidang studi bidang ekonomi memberikan soal berbebtuk lisan dan tulisan dengan tujuan untuk menguji ingatan dan ketanggapan peserta didik dalam penguasaan materi. Pelaksanaan evaluasi formatif yang dilakukan oleh guru bidang studi ekonomi ada pertanyaan yang bentuk lisan maupun tulisan.

\section{Tindaklanjut hasilnya}

Tindaklanjut hasil tes akan diberitahukan kepada peserta didik. Bagi peserta didik yang mendapat hasil belajarnya baik dapat meneruskan pembelajaran selanjutnya dan bagi peserta didik yang hasil belajarnya tidak tuntas akan diadakan perbaikan dan pengayaan.

Melakukan tindaklanjut dari hasil belajar peserta didik, bagi peserta didik yang tuntas hasil belajarnya akan diberikan motivasi, arahan dan bimbingan agar tetap aktif dalam pembelajaran dengan tujuan meningkatkan kemampuan agar menjadi lebih baik lagi. Begitu juga halnya dengan peserta didik yang belum tuntas hasil belajarnya akan dilakukan tindakan pengayaan untuk perbaikan hasilnya.

\section{KESIMPULAN}

Pada akhir penulisan ini, dikemukakan kesimpulan berdasarkan temuan-temuan dari hasil pembahasan pelaksanaan evaluasi formatif mata pelajaran ekonomi pada kelas XI di Aliyah Al-Badar Kasongan pada kelas XI, kesimpulan dalam penelitian ini adalah:

1). Perencanaan merupakan persiapan yang dilakukan oleh guru bidang studi ekonomi sebelum melaksanakan evaluasi formatif, yaitu menyusun silabus dan RPP, sehingga pelaksanaan evaluasi formatif dapat berjalan dengan baik.

2). Pelaksanaan evaluasi formatif mata pelajaran ekonomi yang dilaksanakan di Aliyah Al-Badar sudah sesuai dengan perencanaan guru yang bersangkutan, bahkan sistem pembelajaran yang diajarkan kepada peserta didik mata pelajaran ekonomi sudah berjalan dengan baik walaupun terdapat kekurangan-kekurangan terutama sarana dan prasarana seperti perpustakaan, laboraturium dan buku paket yang sangat minim.

3). Tindaklanjut hasil evaluasi formatif, setelah melaksanakan evaluasi formatif hasil tes tersebut akan diberitahukan kepada peserta didik yang hasil belajarnya baik dapat meneruskan ke pelajaran selanjutnya, tetapi bagi peserta didik yang hasil belajarnya belum mencapai KKM akan diadakan remedial untuk perbaikan hasilnya.

4). Kendala dalam proses pembelajaran yang dihadapi oleh guru adalah penguasaan materi, karena itu guru bidang studi ekonomi harus siap dalam penguasaan materi yang akan disampaikan kepada peserta didik. 
5). Upaya yang dilakukan guru bidang studi ekonomi dalam pelaksanaan evaluasi formatif melakukan perencanaan dengan baik, pengetahuan dan keterampilan yang memadai serta persiapan yang cermat, agar tes formatif yang disusun dapat mengukur tinggi rendahnya kemampuan peserta didik, dari sekian peserta didik ada 14 orang $(93,33 \%)$ yang memenuhi KKM (ketuntasan kriteria mengajar) dan 1 orang $(6,67 \%)$ yang tidak memenuhi KKM dari 15 peserta didik.

\section{DAFTAR PUSTAKA}

Hasan, (2012), Penerapan Kedisiplinan Belajar Mata Pelajaran Ekonomi Bagi Peserta Didik MA Mifhatul Jannah Palangkaraya.

Lexy J. Moleong, (2010), Metodologi Penelitian Kualitatif, Bandung: Remaja Rosdakarya.

Lukmanul Hakim,(2008), Perencanaan Pembelajaran, Bandung: CV. Wacana Prima.

Usman, U, (2005), Menjadi Guru Profesional, Bandung: Remaja Rosdakarya.

Undang - Undang Republik Indonesia Nomor 20 Tahun 2003 tentang Sistim Pendidikan Nasional, 2003 diperbanyak Pusbuk. 